\title{
A Comparative Study of Plant Mediated Synthesis of Silver Nanoparticles from Fresh Leaf Extracts of Gracina Gummi-Gutta L., Cynodon Dactylon L. and Bauhinia Acuminata and Their Antimicrobial Activity Studies
}

\author{
Asha R. Pai ${ }^{1,2}$, Anantha M. Pillai ${ }^{2}$, Abhijith Jayapraksh², Ajith John² \\ ${ }^{1}$ Dept. of Physics, Amrita School of Arts and Sciences, Amrita Vishwa Vidyapeetham, Amritapuri, Kollam -690525. \\ ${ }^{2}$ Amrita School of Biotechnology, Amrita Vishwa Vidyapeetham, Amritapuri, Kollam -690525. \\ Corresponding author. E-mail: asharp@am.amrita.edu
}

Received: Oct. 27, 2016; Accepted: Dec. 9, 2016; Published: Dec. 21, 2016.

Citation: Asha R. Pai, Anantha M. Pillai, Abhijith Jayapraksh, and Ajith John, A Comparative Study of Plant Mediated Synthesis of Silver Nanoparticles from Fresh Leaf Extracts of Gracina Gummi-Gutta L., Cynodon Dactylon L. and Bauhinia Acuminata and Their Antimicrobial Activity Studies. Nano Biomed. Eng., 2016, 8(4): 288-296.

DOI: $10.5101 /$ nbe.v8i4.p288-296.

\begin{abstract}
Metallic nanoparticles traditionally synthesized by wet chemical synthesis techniques used chemicals used which were quite often toxic and flammable. So a reliable and eco-friendly process for synthesis of metallic nanoparticles has become an important step in the field of nanotechnology. Plant extracts are eco-friendly and are economic and efficient alternatives for the large-scale synthesis of nanoparticles. The present study is planned to compare the biosynthesis of silver nanoparticles using the fresh leaf extracts of three potential plants with high medicinal value such as Gracinia gummi gutta L. (Gracinia cambogia), Cynodon dactylon L. and Bauhinia acuminata. A rapid reduction of silver ions leading to the formation of stable silver nanoparticles in solution in 5 minutes at room temperature as compared to that on heating was studied. The UV-Visible spectrum of silver nanoparticles in aqueous solution shows an absorbance peak around $435 \mathrm{~nm}$ due to surface plasmon resonance. Transmission electron microscope images showed the particle size as around $10 \mathrm{~nm}$ and their hydrodynamic size were obtained to be around $100 \mathrm{~nm}$. This is a first attempt to perform ecofriendly synthesis of silver nanoparticles using fresh green leaves of Gracinia gummi-gutta L and produced the maximum yield which may benefit various industries with wide range of applications. These biologically synthesized silver nanoparticles were tested for antibacterial activity against three human pathogens such as Escherichia coli, Pseudomonas aeroginosa, and Staphylococcus aureus. An effective synthesis of silver nanoparticles using aqueous leaf extracts of Gracinia gummi-gutta L. was there by investigated.
\end{abstract}

Keywords: Silver nanoparticles; Gracinia gummi-gutta L.; Cynodon dactylon; Bauhinia acuminata; TEM; Hydrodynamic size

\section{Introduction}

Metallic nanomaterials have the potential ability to alter and improve the pharmacokinetic and pharmaco dynamic properties of various types of drug molecules. The metallic stable dispersions of especially gold, silver and copper are highly useful in areas such as microbiology, surface enhanced Raman 
scattering (SERS) detection, photography, catalysis, biological labeling, photonics and optoelectronics. Silver nanoparticles are of particular interest based on their applications in medical devices and healthcare products because of their antibacterial activity and low toxicity to the human cells. In medicine, silver and silver nanoparticles have ample applications such as skin ointments and creams which contain silver to prevent infection of burns and open wounds [1], medical devices and implants prepared with silverimpregnated polymers [2]. Therefore there is still a need of economic commercially viable as well as environmentally clean synthesis routes to synthesis these nanoparticles.

On the other hand it is seen that the plant extracts, being safer to handle and a source of several metabolites [3], are eco-friendly, economical and cost effective for synthesis of large scale of nanoparticles compared to the other biological synthesis methods using fungi or microbial cultures [4,5]. Many reports are available on the biogenesis of silver nanoparticles using several plant extracts, such as Zea mays [6], Azadirachta indica (Neem) [7], Medicago sativa (Alfa alfa) [8, 9], Aloe vera [10], Emblica officinalis (Amla) [3], Capsicum annuum [11], Geranium sp. [12, 13], Diopyros kaki [14], Magnolia kobus [15], Coriandrum sp. [16], Catharanthusroseus [17], Stigmaphyllonlittorale [18], etc. In this investigation we present a comparative study of the rapid green synthesis of silver nanoparticles (Ag NPs) from green extracts of Bauhinia acuminata, Cynodon dactylon and Gracinia gummi-gutta L. and their characterisation and their inhibitory effects against Gram negative and Gram positive bacteria.

Bauhinia acuminata (Fabaceae family, sub family -
Caesalpinioideae) is a semi-deciduous large shrub with white butterfly like flowers [19]. This species occurs widely in deciduous forests and scrub. Other common names include Dwarf white bauhinia (English), Safed Kachnar (Hindi) and Sivamalli (Sanskrit).

Cynodon dactylon L. (Poaceae family, sub family Chloridoideae) is a perennial weedy grass and is one of the ten auspicious herbs that constitute the group 'Dasapushpam' in Ayurveda [20]. It is reported to be the most sacred plant of India next to Ocimum [21]. Common names around the world include Bermuda grass (English), Doorwa (Sanskrit).

Garcinia cambogia or Garcinia gummi-gutta L (Clusiaceae family) [22] is a tropical species native to Indonesia. This plant is grown for its fruit which looks like a small pumkin in Southeast Asia, coastal Karnataka/ Kerala, India, and west and central Africa. Along the west coast of South India it is popularly termed as Malabar tamarind. The extract and rind of $G$. gummi-gutta is a curry condiment in India especially for its sour flavors and is also purported as a potential antiobesity agent.

\section{Materials and Methods}

Silver nitrate was purchased from Merck India Ltd (99\%). The fresh green leaves of Bauhinia acuminata, Cynodon dactylon L., Garcinia gummigutta L. were obtained from the neighbourhood of Amrita School of Biotechnology, Amritapuri, Kerala, India. Pseudomonas aureginosa (Rod shaped gram negative bacteria), E coli (gram negative bacteria) and Staphylococcus aureus (gram positive bacteria) were cultured and used for inhibitory studies.

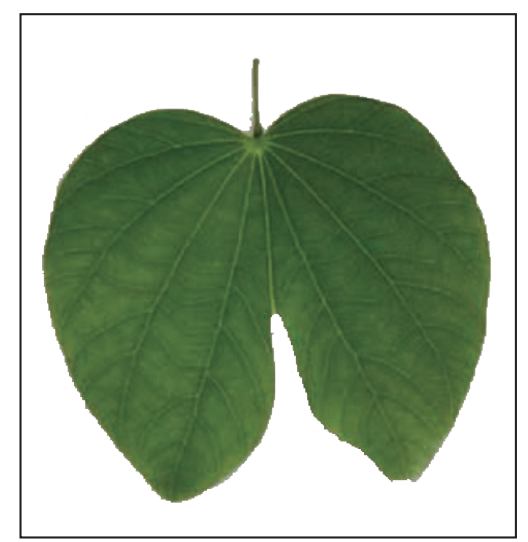

(a)

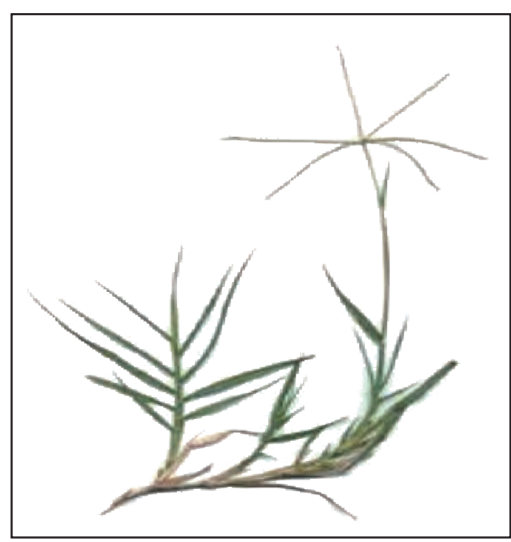

(b)

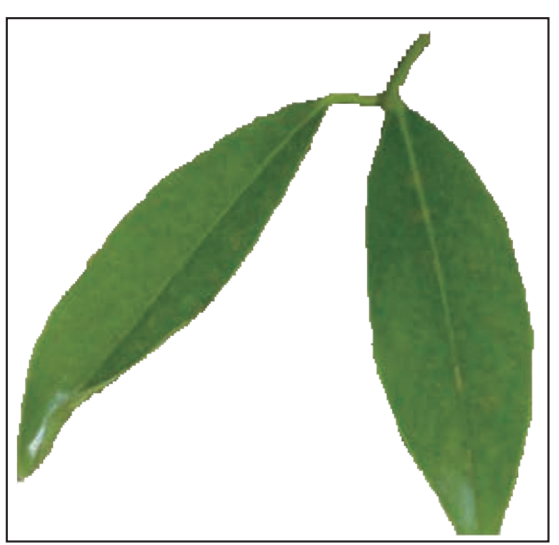

(c)

Fig. 1 Green leaves of (a) Bauhinia acuminata, (b) Cynodon dactylon L., and (c) Garcinia gummi-gutta L. 


\section{Preparation of plant extracts}

All the three plant leaves (Bauhinia Acuminata, Gracinia gummi-gutta L., Cynodon dactylon L.) were washed several times with de-ionized water. $20 \mathrm{~g}$ of thoroughly washed leaves were finely cut into small pieces. $10 \mathrm{~g}$ of the cut leaves were weighed and added to $150 \mathrm{~mL}$ of double distilled water taken in a conical flask and kept under magnetic stirring at $650 \mathrm{rpm}$ for 24 hours. Aqueous extract was separated out using a
Whatmann No1 filter paper. The filtrate was collected and stored at $4{ }^{\circ} \mathrm{C}$ for further use.

\section{Phytochemical screening}

Phytochemical screening of leaf extract (Bauhinia acuminata, Gracinia gummi-gutta L., Cynodon dactylon L.) was done to assess qualitatively the presence of various phytochemical constituents [23-25]. The various tests done are given in Table 1.

Table 1 Phytochemical screening tests (qualitative) for Aqueous green leaf extract of (a) Bauhinia acuminata, (b) Cynodon dactylon L., and (c) Garcinia gummi-gutta L.

\begin{tabular}{|c|c|c|c|c|c|c|c|}
\hline No. & Component & Test Name & Test & Inference & $\begin{array}{l}\text { Cynodon } \\
\text { Dactylon }\end{array}$ & $\begin{array}{l}\text { Bauhinia } \\
\text { Acuminata }\end{array}$ & $\begin{array}{l}\text { Garcinia } \\
\text { Gummi- } \\
\text { Gutta }\end{array}$ \\
\hline 1 & Alkaloids & Wagner's Test & $\begin{array}{l}\text { Filtrates were treated with Wagner's } \\
\text { reagent (Iodine in Potassium Iodide). }\end{array}$ & Brown/reddish precipitate & ++ & ++ & -- \\
\hline 2 & Carbohydrates & Benedict's Test & $\begin{array}{l}\text { Filtrates were treated with Benedict's } \\
\text { reagent and heated gently. }\end{array}$ & Orange red precipitate & -- & ++ & ++ \\
\hline 3 & & Fehling's Test & $\begin{array}{l}\text { Filtrates were hydrolyzed with dil. } \\
\mathrm{HCl} \text {, neutralized with alkali and heated } \\
\text { with Fehling's A \& B solutions. }\end{array}$ & Red precipitate & - & ++ & -- \\
\hline 4 & Saponins & Froth Test & $\begin{array}{l}\text { Extracts were diluted with distilled } \\
\text { water to } 20 \mathrm{~mL} \text { and this was shaken in } \\
\text { a graduated cylinder for } 15 \text { minutes. }\end{array}$ & $1 \mathrm{~cm}$ layer of foam & ++ & -- & -- \\
\hline 5 & & Foam Test & $\begin{array}{l}0.5 \text { gm of extract was shaken with } \\
2 \mathrm{~mL} \text { of water. }\end{array}$ & $\begin{array}{l}\text { If foam produced persists after } \\
\text { shaking for } 10 \text { minutes. }\end{array}$ & ++ & -- & -- \\
\hline 6 & Tanins & Gelatin Test & $\begin{array}{l}\text { To the extract, } 1 \% \text { gelatin solution } \\
\text { containing sodium chloride was added. }\end{array}$ & White precipitate & ++ & -- & -- \\
\hline 7 & & Lead acetate Test & $\begin{array}{l}\text { Small quantities of the extracts were } \\
\text { taken separately in water and tested for } \\
\text { the presence of tannins with } 10 \% \text { lead } \\
\text { acetate solution. }\end{array}$ & White precipitate & ++ & -- & ++ \\
\hline 8 & Phenols & FeCl3 Test & $\begin{array}{l}\text { Extracts were treated with 3-4 drops of } \\
\text { ferric chloride solution. }\end{array}$ & Bluish black colour & ++ & ++ & -- \\
\hline 9 & Flavonoids & $\begin{array}{l}\text { Alkaline Reagent } \\
\text { Test }\end{array}$ & $\begin{array}{l}1 \mathrm{~mL} \text { of filtrate and add } 2 \mathrm{~mL} \\
\text { of dilute } \mathrm{NaOH} \text {. }\end{array}$ & $\begin{array}{l}\text { Blue to violet colour (anthocyanins), } \\
\text { yellow colour (flavones), yellow to } \\
\text { orange (flavonones) }\end{array}$ & ++ & ++ & ++ \\
\hline 10 & & $\begin{array}{l}\text { Lead Acetate } \\
\text { Test (Phenolic } \\
\text { Flavonoids) }\end{array}$ & $\begin{array}{l}1 \mathrm{~mL} \text { of filtrate add } 2 \mathrm{~mL} \text { of } 10 \% \\
\text { lead acetate. }\end{array}$ & Yellow precipitate (Flavones) & ++ & -- & ++ \\
\hline 11 & Proteins & $\begin{array}{l}\text { Xanthoproteic } \\
\text { Test }\end{array}$ & $\begin{array}{l}\text { The extracts were treated with few } \\
\text { drops of conc. Nitric acid. }\end{array}$ & Yellow colour & ++ & ++ & ++ \\
\hline 12 & Amino acids & Ninhydrin Test & $\begin{array}{l}\text { To the extract, } 0.25 \% \mathrm{w} / \mathrm{v} \text { ninhydrin } \\
\text { reagent was added and boiled for few } \\
\text { minutes. }\end{array}$ & Blue colour & +- & ++ & - - \\
\hline 13 & Diterpenes & $\begin{array}{l}\text { Copper Acetate } \\
\text { Test }\end{array}$ & $\begin{array}{l}\text { Extracts were dissolved in water and } \\
\text { treated with } 3-4 \text { drops of copper acetate } \\
\text { solution. }\end{array}$ & Emerald green colour & -+ & ++ & ++ \\
\hline 14 & $\begin{array}{c}\text { Cardiac } \\
\text { Glycosides }\end{array}$ & $\begin{array}{l}\text { Keller Killiani } \\
\text { Test }\end{array}$ & $\begin{array}{l}\text { To } 0.5 \mathrm{~g} \text { of extract diluted to } 5 \mathrm{~mL} \text { in } \\
\text { water was added } 2 \mathrm{~mL} \text { of glacial acetic } \\
\text { acid containing one drop of ferric } \\
\text { chloride solution. This was underlayed } \\
\text { with } 1 \mathrm{~mL} \text { of concentrated sulphuric } \\
\text { acid. }\end{array}$ & $\begin{array}{l}\text { A brown ring at the interface } \\
\text { indicated the presence of a } \\
\text { deoxysugar characteristic of } \\
\text { cardenolides. A violet ring may } \\
\text { appear below the brown ring, while } \\
\text { in the acetic acid layer a greenish } \\
\text { ring may form just above the brown } \\
\text { ring and gradually spread throughout } \\
\text { this layer. }\end{array}$ & 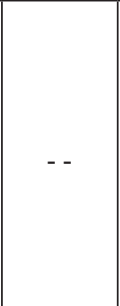 & -- & -- \\
\hline
\end{tabular}




\section{Synthesis of silver nanoparticles}

\section{Room temperature method}

$0.0001 \mathrm{M}$ silver nitrate solution was prepared and taken in a conical flask. $25 \mathrm{~mL}$ plant extract (Bauhinia acuminata, Gracinia gummi-gutta L., Cynodon dactylon L.) was added dropwise constantly to $10 \mathrm{~mL}$ of $\mathrm{AgNO}_{3}$ solution. Solution was kept on magnetic stirring at $200 \mathrm{rpm}$ for 30 minutes -2 hours.

$\mathrm{AgNO}_{3} \rightarrow \mathrm{Ag}^{+}+\mathrm{NO}^{3-}$

$\mathrm{Ag}^{+}+2 \mathrm{H}_{2} \mathrm{O} \rightarrow \mathrm{Ag}^{0}+4 \mathrm{H}^{+}+\mathrm{O}_{2}$

The reduction process was complete when the solution turned brownish-black which confirmed the presence of nanoparticles.

\section{Direct heating method}

$0.0001 \mathrm{M}$ silver nitrate solution was prepared and taken in a conical flask. $25 \mathrm{~mL}$ plant extract (Bauhinia acuminata, Gracinia gummi-gutta L., Cynodon dactylon L.) was added dropwise constantly to $10 \mathrm{~mL}$ of $\mathrm{AgNO}_{3}$ solution and heating at $60{ }^{\circ} \mathrm{C}$. Solution was kept on magnetic stirring at $200 \mathrm{rpm}$ for 30 minutes. The reduction process was complete when the solution turned brownish-black which confirmed the presence of nanoparticles.

\section{Characterisation of the synthesised silver nanoparticles}

\section{Visual observation and standardisation}

The bioreduction of silver ions was observed by the colour changes from pale green to pale yellow and then to dark brown. The periodic monitoring of the variation of absorption was done using the calorimetry.

\section{Uv-vis spectroscopy}

The UV-Vis spectra of the solution were studied using UV-Vis spectrophotometer. UV-Vis spectroscopy measurements of synthesized silver nanoparticles were characterized by Perkin Elmer UV-Vis spectrophotometer. The scanning range of the samples was $200-800 \mathrm{~nm}$ at a resolution of $1 \mathrm{~nm}$.

\section{Particle size analysis using dynamic light scattering (DLS) technique}

In order to find out the particle size distribution the Ag nanoparticle dispersed in water was studied and the data on particle size were extracted using a Zetasizer Nicomp, 390ZLS (Nicomp, USA) using DLS method.

\section{Transmission electron microscopy (TEM)}

Samples for TEM analysis were prepared by placing a drop of the silver nanoparticle solution on the TEM copper grid and were dried. The analysis was done using Philips CM200 at operating voltages of 20-200 $\mathrm{KV}$ and a resolution of 2.4 . The TEM measurements were performed and the morphology of the AgNPs was obtained from the micrographs.

\section{Antimicrobial activity and minimal inhibitory concentration (MIC)}

The antimicrobial activity of AgNPs was evaluated against Gram positive; Staphylococcus aureus, Gram negative; Escherichia coli, Pseudomonas aureginosa by agar well diffusion assay method. 24hour old cultures were prepared in nutrient broth and the optical density, OD, was measured based on the turbidity measurement to confirm the lag phase stage while inoculation. Approximately $25 \mathrm{~mL}$ of the Muller Hinton Agar was poured in the sterilized Petri dishes and plates were prepared. Two replicas of the respective microorganisms were prepared by spreading $100 \mu \mathrm{L}$ of revived culture on the agar plates with the help of a spreader. Well were bored into it and labeled and loaded with various concentrations Silver nano liquid and incubated for 24 hours at $37{ }^{\circ} \mathrm{C}$. The plates were then examined for the confirmation of zone of inhibitions (ZOI) which became visible as the clear area around the wells. The diameters of these ZOI were measured using a meter scale and the mean value for each organism was recorded in millimeters. The lowest concentration of the AgNPs at which the isolate was completely inhibited (absence of any visible bacterial growth) was recorded as the minimal inhibitory concentration or MIC.

\section{Results and Discussions Standardisation}

Fig. 2 (a) and (b) shows the variation of OD measured at $440 \mathrm{~nm}$ for AgNPs synthesized from Bauhinia acuminata, Gracinia gummi-gutta L., Cynodon dactylon L. using heating and without heating methods. It is very clear from the figures that maximum AgNPs which were formed due to heating method and also from the leaf extract of Gracinia cambogia. OD measurements also showed that the maximum AgNPs formed were stable at around 30 minutes for heating method. Hence AgNPs synthesized from heating method was used for comparison.

\section{UV-Vis analysis of AgNPs}

Figs. $3,4 \& 5$ show the UV-Vis absorption spectra 
Effect of heating

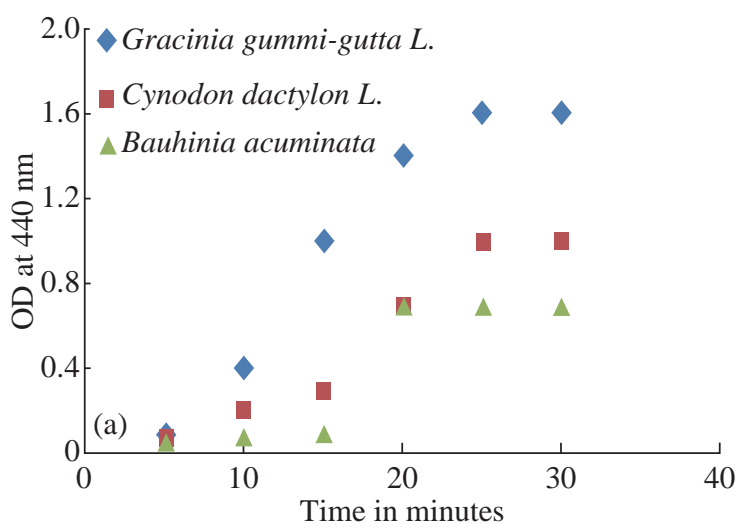

Effect of without heating

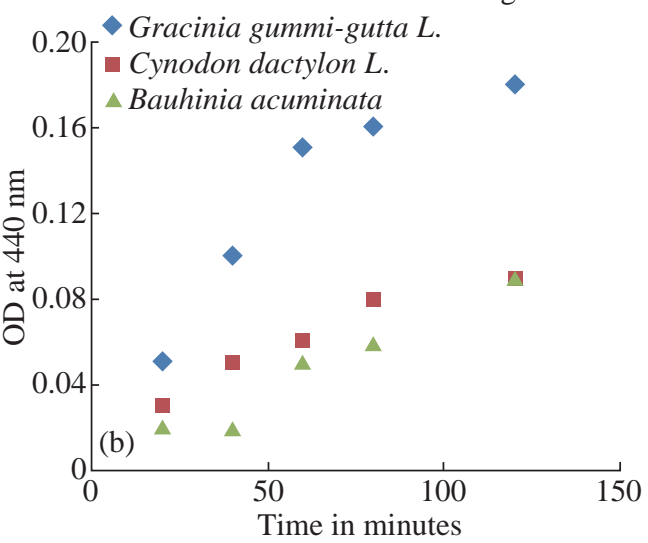

Fig. 2 (a) Effect of heating and (b) without heating on the OD (measured at $440 \mathrm{~nm}$ ) of the AgNPs, synthesized from different plant extracts.
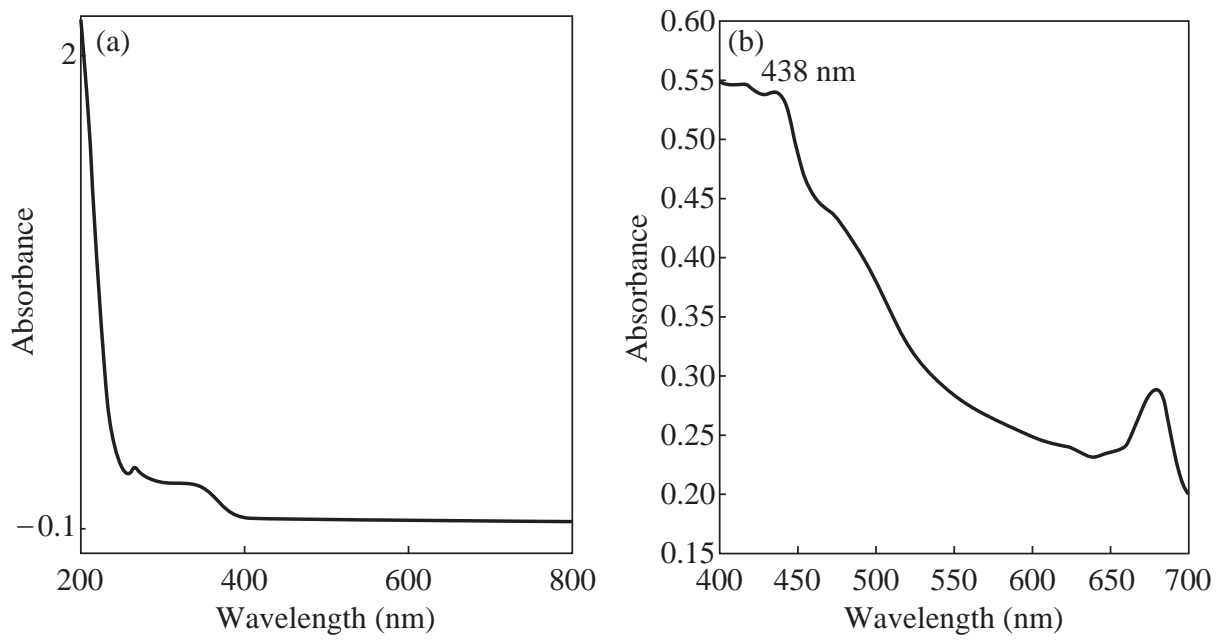

Fig. 3 UV-Visible absorption spectra of (a) green leaf extract of Gracinia gummi-gutta L. and (b) the AgNPs synthesized with heating.
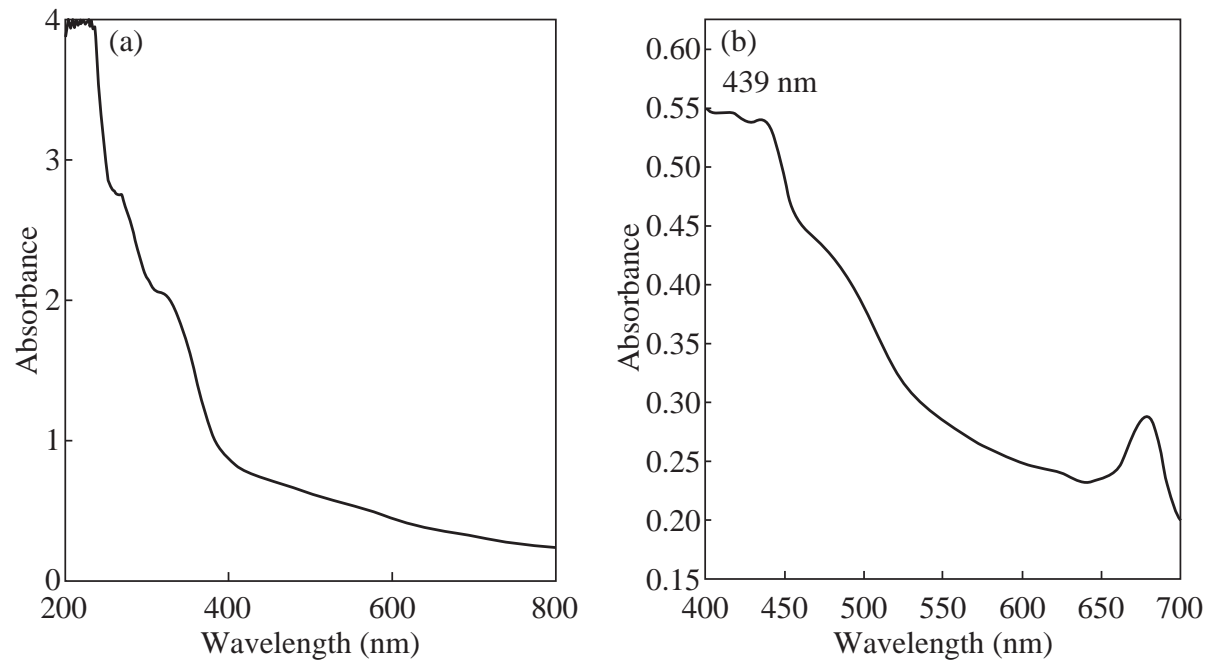

Fig. 4 UV-Visible absorption spectra of (a) green leaf extract of Cynodon dactylon and (b) the AgNPs synthesized with heating.

of the various plant extract and the AgNPs synthesized from their leaf extracts by heating methd. Table 2 gives the absorption maxima of the AgNPs synthesized from the various extracts. It clearly shows the formation of AgNPs. 

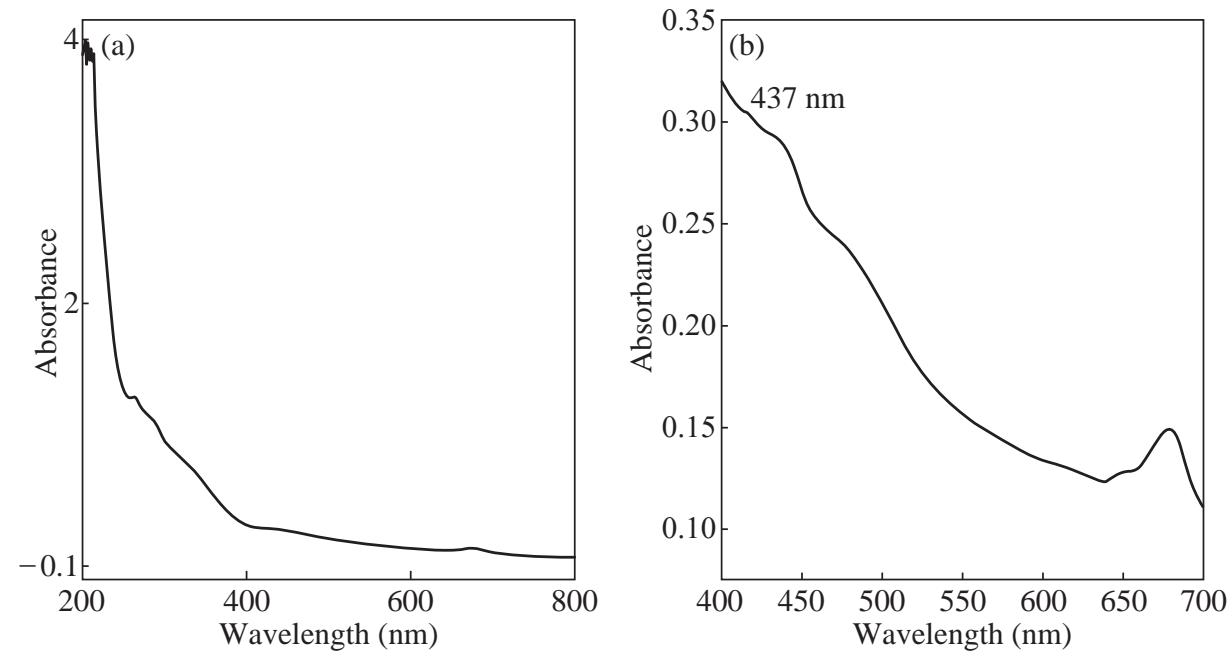

Fig. 5 UV-Visible absorption spectra of (a) green leaf extract of Bauhinia acuminata and (b) the AgNPs synthesized with heating.

Table 2 Maximum absorption (nm) for AgNP's synthesized from fresh leaf extracts

\begin{tabular}{cc}
\hline Ag NP's synthesized from & Maximum absorption (nm) \\
\hline Gracinia gummi-gutta L. & 438 \\
Cynodon dactylon L. & 439 \\
Bauhinia acuminata & 437 \\
\hline
\end{tabular}

\section{Particle size determination - DLS analysis}

The particle size distribution for AgNPs synthesized from various plants by heating method is given in Figs. $6,7,8 \& 9$. Their hydrodynamic diameters were in the range of $100 \mathrm{~nm}$. The AgNPs from Gracinia gummigutta L. leaf extract using heating method had minimal diameter.

\section{TEM analysis of AgNPs}

TEM imaging was carried out to visualize the shape, size and dispersity of the nanoparticles. The TEM image as in Fig. 10 (b) shows that the synthesized

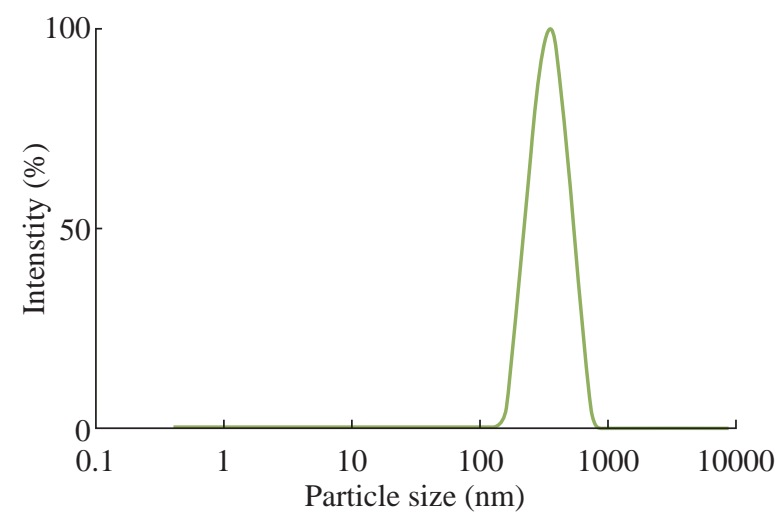

Fig. 6 Particle size analysis of silver nanoparticles synthesized from Gracinia gummi-gutta L. without heating leaf extract.

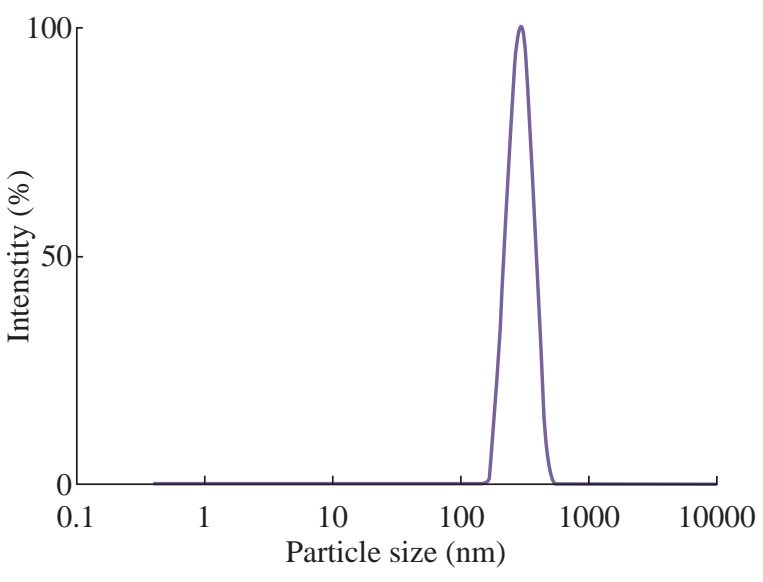

Fig. 7 Particle size analysis of silver nanoparticles synthesized from Gracinia gummi-gutta L. with heating leaf extract.

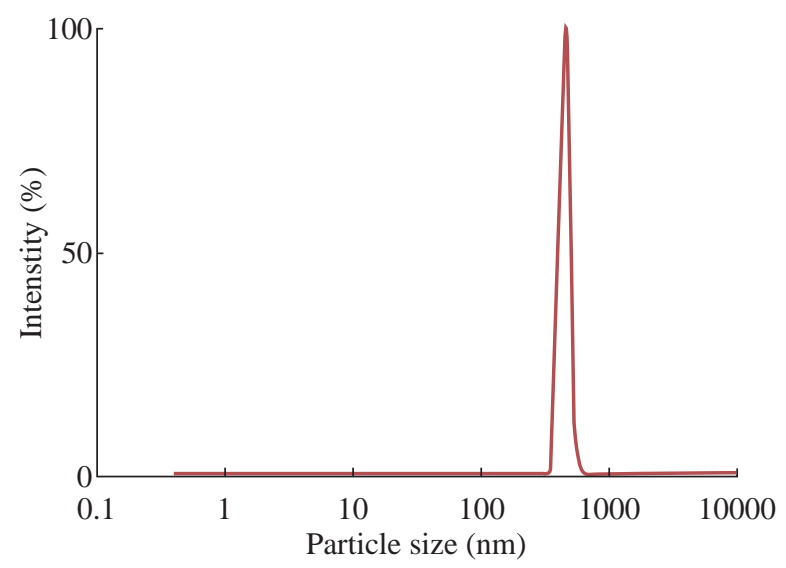

Fig. 8 Particle size analysis of silver nanoparticles synthesized from Cynodon dactylon leaf extract with heating.

AgNPs from fresh leaf extract of Gracinia gummigutta L. with heating were found to be monodispersed, spherical in shape with sizes $<10 \mathrm{~nm}$. 


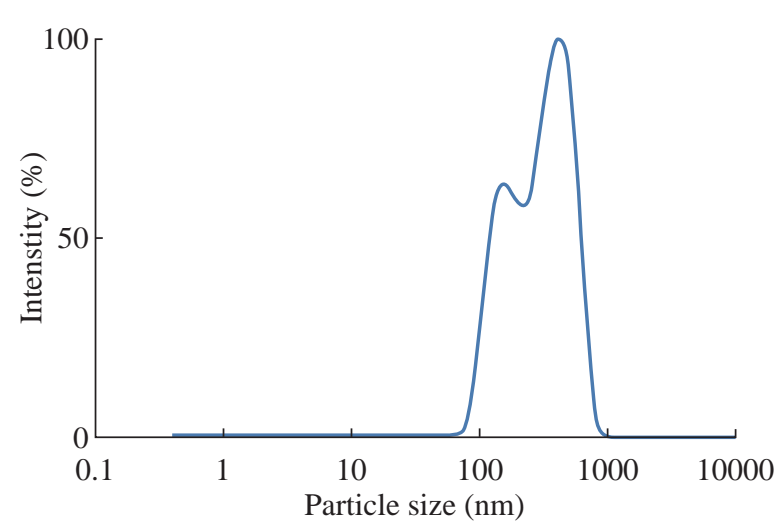

Fig. 9 Particle size analysis of Silver nanoparticles synthesized from Bauhinia acuminata leaf extract with heating.

\section{Antimicrobial activity}

Fig. 11 shows the different zones of inhibition for AgNPs against Gram negative bacteria's $P$. aureginosa. Controlled experiment with only leaf extracts (blank) does not show any zone of inhibition indicating no antimicrobial activity by the leaf extracts. The AgNPs showed pronounced antimicrobial activity against both types of bacteria. It can be seen from Figs. 1214 that the AgNPs showed higher zone of inhibition of $S$. aureus and P. aureginosa than for E. coli. Fig. 15 shows a comparative study of $\%$ inhibition of silver nanoparticles from various plant extracts with the
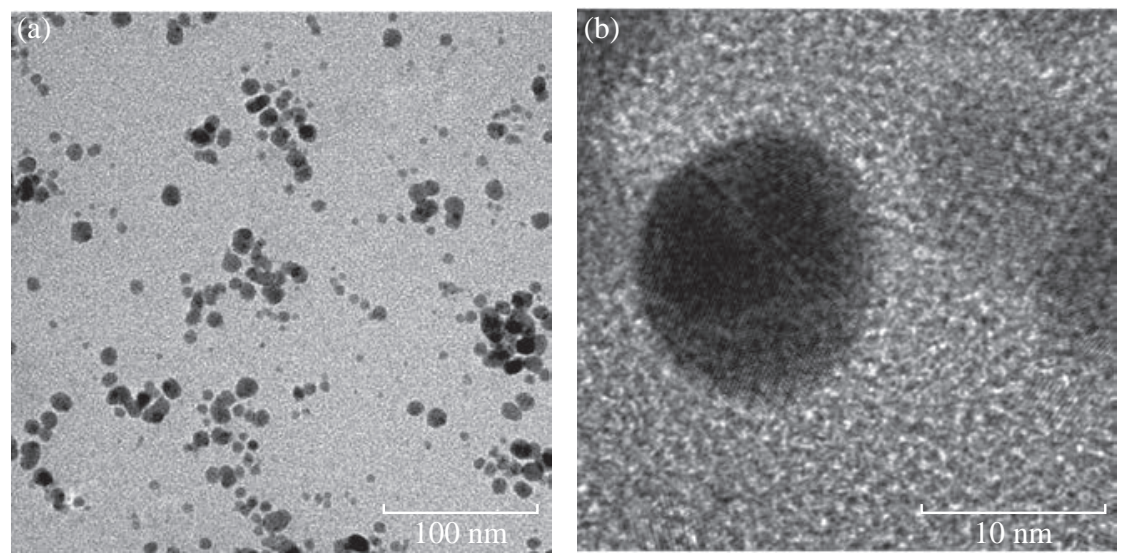

Fig. 10 TEM images of AgNP's synthesized from the fresh leaf extract of Gracinia gummi-gutta L. in two different magnifications.
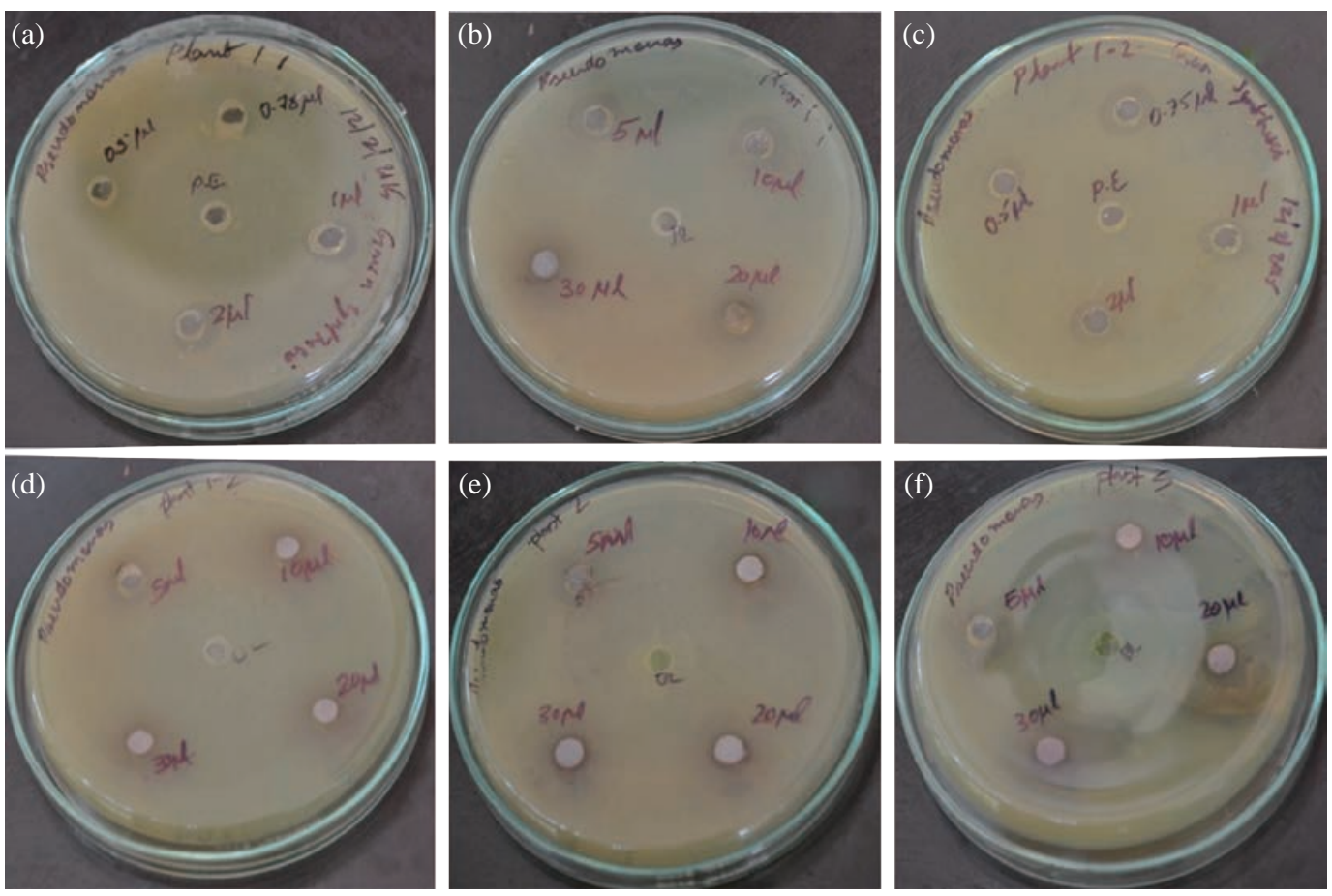

Fig. 11 Agar plates showing the zone of inhibitions against the human pathogen Pseudomonas aureginosa using various concentrations $(0.5 \mu \mathrm{L}, 0.75 \mu \mathrm{L}, 1 \mu \mathrm{L}, 2 \mu \mathrm{L}, 5 \mu \mathrm{L}, 10 \mu \mathrm{L}, 20 \mu \mathrm{L}, 30 \mu \mathrm{L})$ of AgNP's synthesized from (a, b) Garcinia gummi-gutta L. without heating the extract, (c, d) Garcinia gummi-gutta L. with heating the extract, (e) Cynodon dactylon L., and (f) Bauhinia Acuminata. 


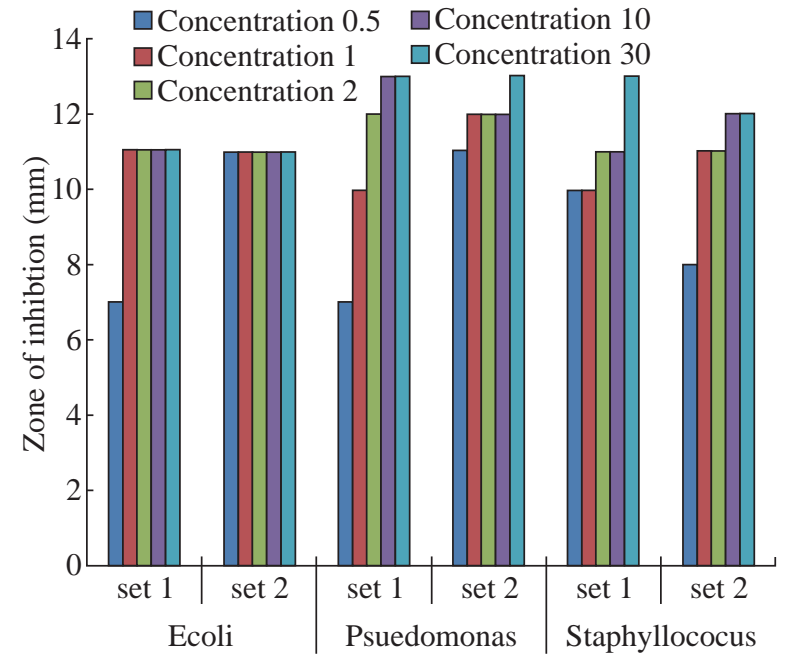

Fig. 12 A comparative study of the antimicrobial activity of various concentrations concentrations $(0.5 \mu \mathrm{L}, 1 \mu \mathrm{L}, 2 \mu \mathrm{L}$, $10 \mu \mathrm{L}, 30 \mu \mathrm{L})$ of AgNPs synthesized from Garcinia gummigutta L. without heating the extract (set 1) and with heating the extract (set 2) against pathogenic bacteria E. Coli, Pseudomonas aureginosa, Staphylococcus aureus strains.

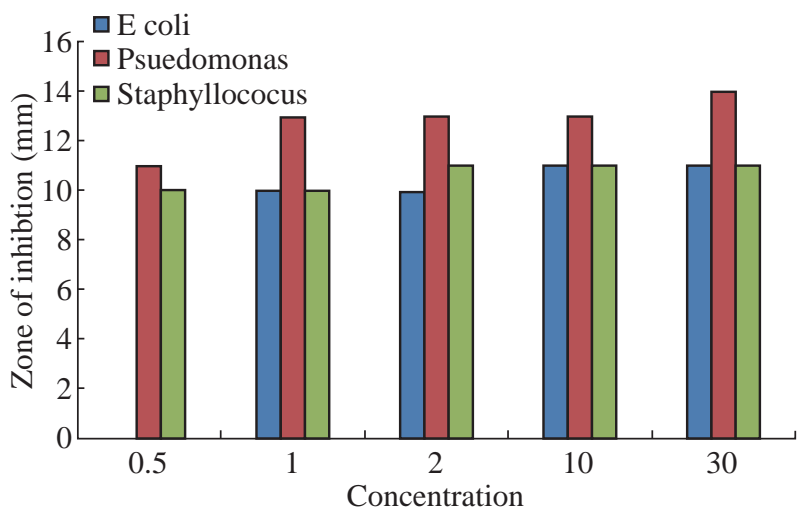

Fig. 13 A comparative study of the antimicrobial activity of various concentrations $(0.5 \mu \mathrm{L}, 1 \mu \mathrm{L}, 2 \mu \mathrm{L}, 10 \mu \mathrm{L}, 30 \mu \mathrm{L})$ of AgNPs synthesized from Cynodon dactylon green extract against pathogenic bacteria E. Coli, Pseudomonas aureginosa, Staphylococcus aureus strains.

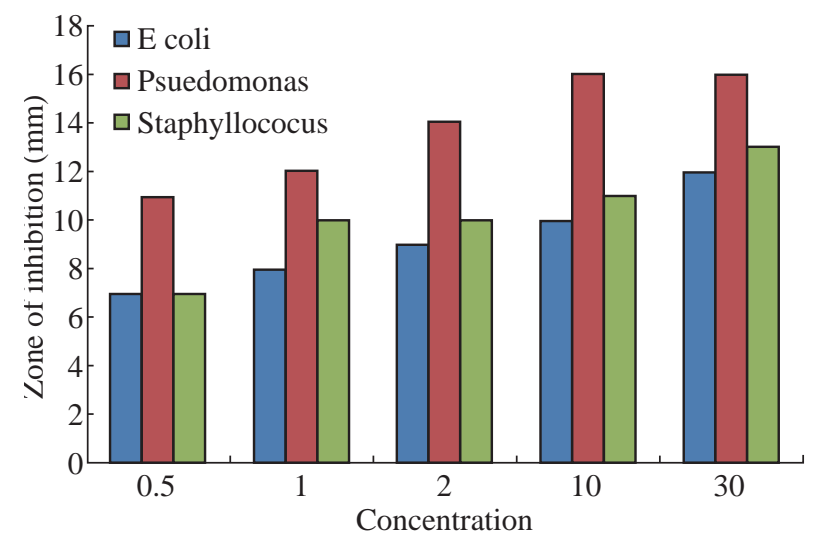

Fig. 14 A comparative study of the antimicrobial activity of various concentrations $(0.5 \mu \mathrm{L}, 1 \mu \mathrm{L}, 2 \mu \mathrm{L}, 10 \mu \mathrm{L}, 30 \mu \mathrm{L})$ of AgNPs synthesized from Bauhinia acuminata leaf extract against pathogenic bacteria E. Coli, Pseudomonas aureginosa, Staphylococcus aureus strains.

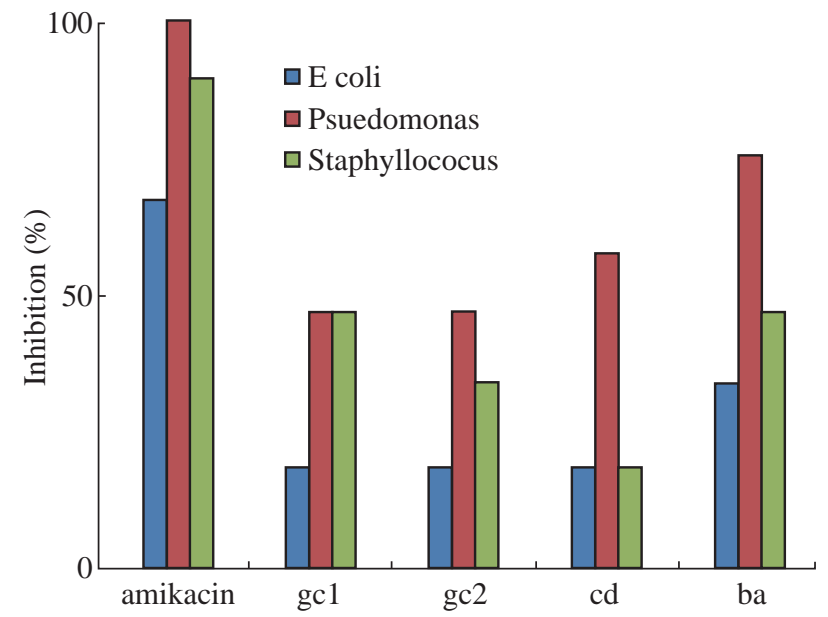

Fig. 15 A comparative study of \% inhibition of $30 \mu \mathrm{L}$ of AgNPs synthesized from leaf extracts of Garcinia gummi-gutta L. without heating the extract $(\mathrm{gcl})$ and with heating the extract (gc 2), Cynodon dactylon (cd) and Bauhinia acuminata (ba) and standard Amikacin against pathogenic bacteria E. Coli, Pseudomonas aureginosa, Staphylococcus aureus strains.

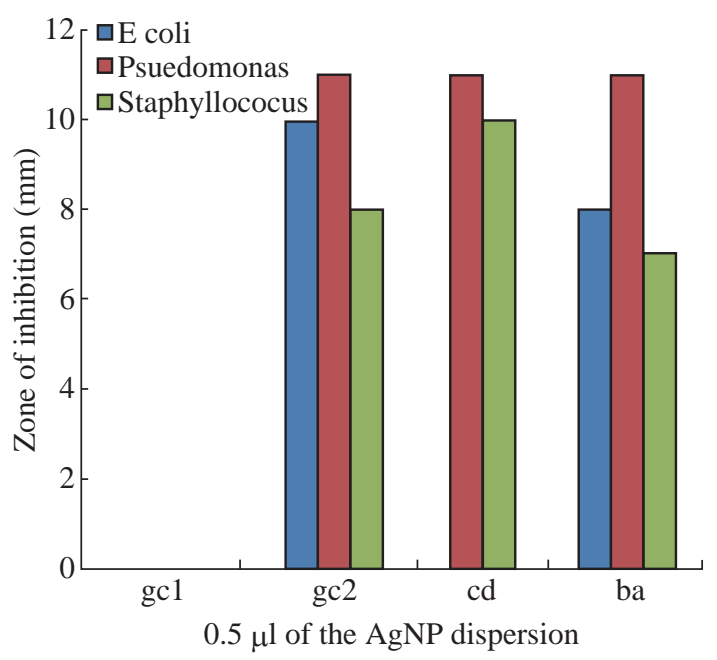

Fig. 16 Comparison of the ZOI's of AgNP's derived from leaves of Garcinia gummi-gutta L. without heating the extract ( $\mathrm{gc1}$ ) and with heating the extract (gc 2), Cynodon dactylon (cd) and Bauhinia acuminata (ba) at $0.5 \mu \mathrm{L}$ concentration against pathogenic bacteria like E. Coli, Psuedomonas auerginosa and Staphyllococus aureus strains.

standard drug Amikacin. It can therefore be suggested that the accumulation and absorption of AgNPs on the cell walls of the microbes was more in $S$. aureus and $P$. aureginosa.

\section{Minimum inhibitory concentrations}

The minimum inhibitory concentration for the AgNP derived from different plants is given in Fig. 16. It is clear that the AgNP's derived by heating method from the leaves of Gracinia gummi-gutta L. were showing pronounced inhibition at even $0.5 \mu \mathrm{L}$ concentration. 


\section{Conclusions}

The current study gives a comparison between the biosynthesis of AgNPs by using the aqueous extracts of the fresh leaves of Garcinia gummi-gutta L., Cynodon dactylon L. and Bauhinia acuminata. The plant extract acts both as a reducing and a capping agents, giving rise to spherical AgNPs. The biosynthesized nanoparticles were characterized by UV-Vis spectroscopy, DLS analysis and TEM. AgNPs were crystalline in nature; the size of the silver nanoparticles was in the range of $20 \mathrm{~nm}$, and their hydrodynamic sizes were around $100 \mathrm{~nm}$. The biosynthesized AgNPs had antibacterial activity and are probable candidates for medical applications, especially in drug delivery process.

\section{Acknowledgements}

The authors would like to thank the operators and staff of Amrita Centre for Nanoscience and Nanomedicine, Kochi for the characterisation facility provided there. The authors also like to thank Dr. Bipin Nair, Dean and the staff of Amrita school of Biotechnology, Amritapuri and also would like to mention the BRITE initiatives at Amrita School of Biotechnology, Amritapuri for which this project was considered.

\section{References}

[1] N. Durán, P.D. Marcato, O.L. Alves, et al., Mechanistic aspects of biosynthesis of silver nanoparticles by several Fusarium oxysporum strains. J Nanobiotechnology, 2005, 3: 8 .

[2] T. Klaus, J. Ralph, O. Eva, et al., Silverbased crystalline nanoparticles, microbially fabricated. Proc Natl Acad Sci USA, 1999, 96: 13611.

[3] B. Ankamwar, C. Damel, A. Ahmad, et al., Biosynthesis of gold and silver nanoparticles using Emblics Officinalis Fruit extract and their Phase Transfer and Transmetallation in an Organic Solution. J nanosci nanotechnol, 2005, 5(10): 1665 .

[4] M. Sastry, A. Absar, M.K. Islam, et al., Biosynthesis of metal nanoparticles using fungi and actinomycetes. Current Sc., 2003, 85(2): 162.

[5] M. Sastry, A. Absar, M.K. Islam, et al., Microbial nanoparticle production. Nanobiotechnology: Concepts, Applications and Perspectives, 2003, 85(2): 163.

[6] A. Leela, M. Vivekanandan, Tapping the unexploited plant resources for the synthesis of silver nanoparticles. African J. of Biotechnol., 2008, 7: 3162.

[7] S.S. Shankar, R. Akhilesh, A. Absar, et al., Rapid synthesis of Au, Ag, and bimetallic Au core-Ag shell nanoparticles using Neem (Azadirachta indica) leaf broth. J. Colloid Interface Sci., 2004, 275: 496.

[8] J.L. Gardea-Torresdey, J.G. Parsons, E. Gomez, et al., Formation and growth of Au nanoparticles inside live alfalfa plants. Nano Lett., 2002, 2: 397.
[9] J.L. Gardea-Torresdey, J.G. Parsons, J.R. Peralta-Videa, et al., Alfalfa sprouts: a natural source for the synthesis of silver nanoparticles. Langmuir, 2003, 19: 1357.

[10] S.P. Chandran, M. Chaudary, R. Pasricha, et al., Synthesis of gold nanotriangles and silver nanoparticles using Aloe vera plant extract. Biotechnol. Prog., 2006, 22: 577.

[11] S. Li, S. Yuhua, X. Anjian, et al., Green synthesis of silver nanoparticles using Capsicum annuum L. extract. Green Chem., 2007, 9: 852.

[12] S.S. Shankar, A. Ahmad, and M. Sastry, Geranium leaf assisted biosynthesis of silver nanoparticles. Biotechnol. Prog., 2003, 19: 1627.

[13] S.S. Shankar, A. Ahmad, and M. Sastry, Biosynthesis of silver and gold nanoparticles from extracts of different parts of the geranium plant. App. Nano Sci., 2004, 1: 69.

[14] J.Y. Song, B.S. Kim, Biological synthesis of bimetallic $\mathrm{Au} / \mathrm{Ag}$ nanoparticles using Persimmon (Diopyros kaki) leaf extract. Korean J Chem Eng., 2008, 25: 808.

[15] J.Y. Song, J. Hyeon-Kyeong, and B.S. Kim, Biological synthesis of gold nanoparticles using Magnolia kobus and Diopyros kaki leaf extracts. Process Biochem., 2009, 44: 1133.

[16] K.B. Narayanan, N. Sakthivel, Coriander leaf mediated biosynthesis of gold nanoparticles. Mater Lett., 2008, 62: 4588 .

[17] S. Ponarulselvam, C. Panneerselvam, K. Murugan, et al., Synthesis of silver nanoparticles using leaves of Catharanthus roseus L. G. Don and their antiplasmodial activities. Asian Pac. J. Trop. Biomed., 2012, 2(7): 574.

[18] K.R. Karunakar, R.D. Manisha, M. Ramachander, et al., Microwave assisted green synthesis of silver nanoparticles using Stigmaphyllon littorale leaves, their characterization and anti-microbial activity. Int. J. Nanomaterials and biostructures, 2013, 3(1): 13.

[19] N.S. Kumari, S. Tanuja, Phytochemical screening and electrophoretic study of seed storage proteins of Bauhinia acuminate and Cassia occidentalis. Int $J$ recent scientific research, 2013, 4(11): 1812.

[20] G. Sindhu, M. Ratheesh, G.L. Shyni et al., Inhibitory effects of Cynodon dactylon L. on inflammation and oxidative stress in adjuvant treated rats. Immunopharmacol Immunotoxicol, 2009, 31(4): 647-53

[21] P. Rita, A. Mandal, and K.A. Datta, An updated overview on Cynodon dactyolon (L.) Pers. IJRAP, 2012, 3(1): 11.

[22] R. Subashini, S. Sruthi, P. Sindhuja, et al., Biosynthesis of Silver Nanoparticles using Garcinia mangostana Fruit extract and their antibacterial, antioxidant activity. Int $J$ Curr Mirobiol App Sci, 2015, 4(1): 944.

[23] S. Anupriya, E. Kannan, A. Rajamani, et al., Synthesis of Silver nanoparticles stabilised with Phytochemicals and its Application towards Invitro Antioxidant and Antibacterial Activities. Int. J. Med. Nanotech., 2016, 3(2): 340

[24] G.A. Ayoola, H.A.B. Coker, S.A. Adesegun, et al., Phytochemical Screening and Antioxidant Activities of Some Selected Medicinal Plants Used for Malaria Therapy in Southwestern Nigeria. Trop. J. Pharmceu. Res., 2008, 7(3): 1019.

[25] T. Prashant, K. Bimlesh, K. Mandeep, et al., Phytochemical screening and Extraction: A Review. Internationale Pharmaceutica Sciencia, 2011, 1(1): 98.

Copyright $\subset 2016$ Asha R. Pai, Anantha M. Pillai, Abhijith Jayapraksh, and Ajith John. This is an open-access article distributed under the terms of the Creative Commons Attribution License, which permits unrestricted use, distribution, and reproduction in any medium, provided the original author and source are credited. 